\title{
Desulfotomaculum varum sp. nov., a moderately thermophilic sulfate-reducing bacterium isolated from a microbial mat colonizing a Great Artesian Basin bore well runoff channel
}

\author{
Christopher D. Ogg • Bharat K. C. Patel
}

Received: 12 March 2011 / Accepted: 13 July 2011/Published online: 9 August 2011

(C) The Author(s) 2011. This article is published with open access at Springerlink.com

\begin{abstract}
A strictly anaerobic moderately thermophilic bacterium, designated strain $\mathrm{RH} 04-3^{\mathrm{T}}$ ( $\mathrm{T}=$ type strain), was isolated from a red colored microbial mat that colonizes a Great Artesian Basin (GAB) bore well (Registered Number 17263) runoff channel at $66^{\circ} \mathrm{C}$. The cells of strain RH04- $3^{\mathrm{T}}$ were straight to slightly curved, sporulating, Gram-positive rods $(2.0-5.0 \times 1.0 \mu \mathrm{m})$ that grew optimally at $50{ }^{\circ} \mathrm{C}$ (temperature growth range between 37 and $55^{\circ} \mathrm{C}$ ) and at $\mathrm{pH} 7(\mathrm{pH}$ growth range of 5.0 and 8.5). Growth was inhibited by $\mathrm{NaCl}$ concentrations $\geq 1.5 \%$ (w/v), and by chloramphenicol, streptomycin, tetracycline, penicillin and ampicillin. The strain utilized fructose, mannose, glycerol, lactate, pyruvate and $\mathrm{H}_{2}$ in the presence of sulfate, and fermented pyruvate in the absence of sulfate. Strain RH04- $3^{\mathrm{T}}$ reduced sulfate, sulfite, thiosulfate and elemental sulfur, but not nitrate, nitrite, iron(III), arsenate(V), vana$\operatorname{dium}(\mathrm{V})$ or cobalt(III) as terminal electron acceptors. The $\mathrm{G}+\mathrm{C}$ content of DNA was $52.4 \pm 0.8 \mathrm{~mol} \%$ as determined by the thermal denaturation $(\mathrm{Tm})$ method. $16 \mathrm{~S}$ rRNA sequence analysis indicated that strain $\mathrm{RH} 04-3^{\mathrm{T}}$ was a member of the genus Desulfotomaculum and was most closely related to Desulfotomaculum putei (similarity value of $95.2 \%$ ) and Desulfotomaculum hydrothermale (similarity value of 93.6\%). On the basis of phylogenetic and phenotypic characteristics, strain RH04-3 $3^{\mathrm{T}}$ is considered to represent a novel species of the genus Desulfotomaculum, for which the name Desulfotomaculum varum sp. nov. is
\end{abstract}

C. D. Ogg · B. K. C. Patel (ه)

Microbial Gene Research and Resources Facility,

School of Biomolecular and Physical Sciences,

Griffith University, Brisbane, QLD 4111, Australia

e-mail: b.patel@griffith.edu.au proposed. The type strain $\mathrm{RH} 04-3^{\mathrm{T}}=\mathrm{JCM} 16158^{\mathrm{T}}=$ KCTC $5794^{\mathrm{T}}$.

Keywords Desulfotomaculum varum sp. nov · Phylum Firmicutes · Great Artesian Basin · Australia · Phylogeny · Taxonomy

\section{Introduction}

The Great Artesian Basin (GAB) underlies arid and subarid regions of approximately $22 \%$ of the Australian continent and is considered to be the world's most expansive geothermal aquifer (Habermehl 1980). The GAB has an estimated water-storage capacity of $8.7 \times 10^{12} \mathrm{~m}^{3}$ and, since 1878 , more than 5,000 bore wells have been drilled into the GAB to provide a vital water resource for outback Australian communities. Several gas and oil fields are located in the GAB aquifer, and the Queensland State Government and the Australian Commonwealth Government have approved the exploitation of these resources. The GAB aquifer therefore not only supports the domestic activities of over 180,000 outback rural residents, but also supports agriculture-, mineral-, gas- and petroleum-production industries that generate a combined income of approximately $\$ 4$ billion (AUD) per annum to the Australian economy. A significant decrease in GAB bore well pressure and outflow volume has been observed in recent years; since 1999, the Australian Commonwealth Government has invested heavily in a program to cap and control bore wells in order to restore the pressure of the basin. Despite these efforts, water loss from leaky corroded bore wells still occurs, and if this remains unchecked may cause detrimental long-term effects to the future of water storage, pressure and economic value of the GAB. 
It is well documented that sulfate-reducing bacteria (SRB) exert an immense influence on the geochemical properties of deep subsurface environments. Thermal environments including subsurface environments that are heated due to their depth are known to harbor a diverse range of thermophilic SRB belonging to the genera Desulfotomaculum (Campbell and Postgate 1965), Thermodesulfotobacterium (Zeikus et al. 1983), Thermodesulfovibrio (Henry et al. 1994), Thermodesulforhabdus (Beeder et al. 1995), Thermodesulfobium (Mori et al. 2003), Thermodesulfatator (Moussard et al. 2004), Desulfothermus (Kuever et al. 2005), Desulfovirgula (Kaksonen et al. 2007a), Desulfurispora (Kaksonen et al. 2007b) and Thermosulfidibacter (Nunoura et al. 2008). We have previously speculated that the co-colonization of indigenous microbial communities of SRB on the metal-casing of bore wells could significantly increase corrosion processes, and this may eventually lead to total bore well failure. We have previously reported on Desulfotomaculum australicum, a thermophilic SRB isolated from the GAB (Love et al. 1993). In this report, we extend our studies of novel SRB from the GAB and describe a strictly anaerobic, moderately thermophilic, SRB, designated strain RH04- $3^{\mathrm{T}}$, which represents a new species of the genus Desulfotomaculum, for which the name Desulfotomaculum varum is proposed.

\section{Materials and methods}

Sample source and strains

A $66^{\circ} \mathrm{C}$ red-colored microbial mat sample was collected from the run-off channel of the New Lorne Bore well (RN 17263) located near the township of Blackall, some $1,000 \mathrm{~km}$ northwest of Brisbane, Queensland State, Australia $\left(24^{\circ} 54^{\prime} 48^{\prime \prime} \mathrm{S}\right.$ and $\left.145^{\circ} 08^{\prime} 18^{\prime \prime} \mathrm{E}\right)$, and was used in previous studies (Ogg and Patel 2009; Spanevello 2001).

\section{Enrichment and isolation}

Enrichment and isolation were performed in a modified anaerobic Patel Laboratory (PL) medium, which contained ( ${ }^{-1}$ deionized water): $1 \mathrm{~g} \mathrm{NH}_{4} \mathrm{Cl}, 0.6 \mathrm{~g} \mathrm{~K}_{2} \mathrm{HPO}_{4}, 0.3 \mathrm{~g}$ $\mathrm{KH}_{2} \mathrm{PO}_{4}, 0.1 \mathrm{~g} \mathrm{MgCl}_{2} \cdot 6 \mathrm{H}_{2} \mathrm{O}, 1.0 \mathrm{~g} \mathrm{NaCl}, 12.0 \mathrm{~g} \mathrm{HEPES}$ and $0.2 \mathrm{~g}$ yeast extract. The medium was adjusted to $\mathrm{pH}$ 7.2 , heated in an autoclave at $121{ }^{\circ} \mathrm{C}$ and $1-1.5 \mathrm{~kg} \mathrm{~cm}^{-2}$ pressure for $10 \mathrm{~min}$ to remove dissolved oxygen, cooled under a stream of oxygen-free nitrogen gas, and $1 \mathrm{ml}$ vitamin solution $1^{-1}$ (Wolin et al. 1963), $1 \mathrm{ml}$ trace-element solution $1^{-1}$ (Zeikus et al. 1979) and, unless indicated otherwise, $2 \mathrm{ml}$ of $10 \% \mathrm{Na}_{2} \mathrm{~S}$ were added. The medium
Table 1 Results of sulfate reduction with different electron acceptors in enrichment cultures

\begin{tabular}{|c|c|}
\hline Growth substrate (concentration) & Sulfate reduction \\
\hline \multicolumn{2}{|l|}{ Extracts $(0.2 \%)$ : } \\
\hline Tryptone & ++ \\
\hline Peptone & ++ \\
\hline \multicolumn{2}{|l|}{ Alcohols $(0.2 \%)$ : } \\
\hline Ethanol & - \\
\hline Glycerol & ++ \\
\hline \multicolumn{2}{|l|}{ Organic acids $(0.2 \%)$ : } \\
\hline Acetate & - \\
\hline Propionate & - \\
\hline Formate & + \\
\hline Pyruvate & ++ \\
\hline Malonate (5 mM) & - \\
\hline Adipate $(5 \mathrm{mM})$ & + \\
\hline \multicolumn{2}{|l|}{ Aromatic compounds $(4 \mathrm{mM})$ : } \\
\hline Benzoate & - \\
\hline 3-Hydroxybenzoate & - \\
\hline 4-Hydroxybenzoate & - \\
\hline 2,5-Dihydroxybenzoate & - \\
\hline 3-Chlorobenzoate (2 mM) & - \\
\hline Phenylacetate & - \\
\hline 4-Hydroxyphenylacetate & - \\
\hline Cinnamate & - \\
\hline 4-Hydroxycinnamate & - \\
\hline 2-Hydroxycinnamate & - \\
\hline 2-Methoxybenzoate & $+^{\mathrm{a}}$ \\
\hline 4-Methoxybenzoate & $+^{\mathrm{a}}$ \\
\hline Vanilline & - \\
\hline Syringate & - \\
\hline Control (no substrate) & - \\
\hline
\end{tabular}

A deep-well U-bottom microtiter plate was prepared with various substrates listed below and sulfate reduction determined using the methods described in the text

Sulfate reduction is scored as: ++ strong, + weak, - no sulfate reduction

${ }^{\text {a }}$ Subsequent subculture of the enrichment failed to grow

was then dispensed into Hungate tubes under oxygen-free nitrogen gas (Patel et al. 1985) and sterilized for $20 \mathrm{~min}$ at $121{ }^{\circ} \mathrm{C}$ and $1-1.5 \mathrm{~kg} \mathrm{~cm}^{-2}$ pressure. After sterilization, sulfate was added from a sterile anaerobic $1 \mathrm{M}$ stock solution to a final concentration of $20 \mathrm{mM}$. When sulfate was added, the medium was designated $\mathrm{SO}_{4}$-PL medium.

For enrichment studies, $20 \mu \mathrm{l}$ of sterile anaerobic stock solutions of electron donors including extracts, carbohydrates, organic acids and alcohols (10\%) and aromatic compounds $(200 \mathrm{mM})$ listed in Table 1 were dispensed into wells of U-bottom deep-well $(1.2 \mathrm{ml})$ microtiter plates (Sarstedt, Germany). The solutions were dried at $50{ }^{\circ} \mathrm{C}$ for $1 \mathrm{~h}$ and stored inside an anaerobic chamber (Coy 
Laboratory Products, USA) for at least $24 \mathrm{~h}$ to remove any trapped oxygen prior to use. A $5 \%$ suspension of the red mat sample was prepared in $\mathrm{SO}_{4}$-PL medium lacking $\mathrm{Na}_{2} \mathrm{~S}$ and $1 \mathrm{ml}$ inoculated into each well under anaerobic conditions in the anaerobic chamber. The plates were then placed horizontally inside an anaerobic gas jar (Oxoid Ltd., UK), the jars removed from the anaerobic chamber and incubated at $50{ }^{\circ} \mathrm{C}$. After 3 days of incubation, the plates were returned to the anaerobic chamber, cooled for $1 \mathrm{~h}$, and $50 \mu \mathrm{l}$ of $10 \%$ freshly prepared sterile anaerobic stock solution of $\mathrm{Fe}\left(\mathrm{NH}_{4}\right)_{2}\left(\mathrm{SO}_{4}\right)_{2}$ added to each well to give a final concentration of $0.5 \%$. Wells in which black precipitates of ferrous sulfide were produced were suggestive of sulfate reduction and scored as positive for metabolism. Cultures from the positive wells were serially diluted in Hungate tubes containing $\mathrm{SO}_{4}-\mathrm{PL}$ medium and the respective enrichment carbon source and incubated at $50{ }^{\circ} \mathrm{C}$ for 3 days, after which the tube containing the highest dilution was selected and the procedure of serial dilution repeated at least a further two times. A shake tube method was used to isolate pure cultures. For this, the culture was serially diluted in Hungate tubes containing the respective energy substrate amended $\mathrm{SO}_{4}$ - $\mathrm{PL}$ medium, fortified with $1 \%$ gelrite (as a solidifying agent), and wellisolated colonies that developed after 7 days incubation at $50{ }^{\circ} \mathrm{C}$ were picked and subcultured into fresh $\mathrm{SO}_{4}-\mathrm{PL}$ medium amended with the appropriate carbon source. Pure cultures were preserved in a 50:50 mixture of glycerol: $\mathrm{SO}_{4}$-PL medium amended with the appropriate carbon source and stored at $-20{ }^{\circ} \mathrm{C}$.

\section{Microscopy}

Cell morphology of strain RH04- $3^{\mathrm{T}}$ was determined by phase-contrast microscopy and electron microscopy (Kanso and Patel 2003).

\section{Optimum growth conditions}

The growth of strain RH04- $3^{\mathrm{T}}$ was tested at temperatures ranging from 26 to $65{ }^{\circ} \mathrm{C}$ and $\mathrm{pH}$ values ranging from 4.0 to 9.5 .

Studies on electron donor and acceptor

The ability of strain RH04- $3^{\mathrm{T}}$ to utilize fructose, mannose, glycerol, lactate, pyruvate, glucose, lactose, ethanol, malate, acetate, propionate, formate, succinate, casamino acids, benzoate, butyrate, propanol, methanol and butanol was tested in PL medium with or without $20 \mathrm{mM}$ sodium sulfate. For this, the substrates from sterile anaerobic stock solutions $(10 \%)$ were added to the medium at a final concentration of $0.2 \%$. The ability of strain RH04-3 $3^{\mathrm{T}}$ to use $\mathrm{H}_{2}$ or $\mathrm{CO}_{2}$ was tested in 30-ml serum bottles containing $\mathrm{SO}_{4}$ PL medium with or without $2 \mathrm{mM}$ acetate, under $\mathrm{H}_{2}$ $(100 \%)$ or $\mathrm{CO}_{2}(100 \%)$ gas phase. $\mathrm{SO}_{4}$-PL medium lacking the respective substrate was used as a negative control. Substrate utilization was determined as positive when growth and/or sulfate reduction was detected.

Sodium sulfate $(20 \mathrm{mM})$, sodium thiosulfate $(20 \mathrm{mM})$, sodium sulfite $(5 \mathrm{mM})$, elemental sulfur $(1 \%)$, sodium nitrate $(20 \mathrm{mM})$, sodium nitrite $(5 \mathrm{mM})$, fumarate $(20 \mathrm{mM})$, ammonium iron(III) citrate $(0.2 \%)$, sodium arsenate $(5 \mathrm{mM})$, sodium metavanadate $(4 \mathrm{mM})$ and sodium cobalt(III) $(5 \mathrm{mM})$ were tested as electron acceptors in PL medium amended with $0.2 \%$ glycerol. $\mathrm{Na}_{2} \mathrm{~S}$ was excluded from the medium when testing for iron(III), vanadium $(\mathrm{V})$, arsenate $(\mathrm{V})$ and cobalt(III) reduction.

\section{Analytical studies}

Unless indicated otherwise, all experiments were conducted at least twice in triplicate, and cultures were subcultured at least once in the same medium prior to the conduct of the experiment. All growth studies were performed in $\mathrm{SO}_{4}$-PL medium amended with $0.2 \%$ glycerol and incubated for up to 14 days unless otherwise indicated. Growth was measured at $600 \mathrm{~nm}$ by inserting Hungate tubes directly into a modified cuvette holder of a Novaspec LKB spectrophotometer (Pharmacia-Biotech Pty. Ltd). Electron acceptor utilization was determined by measuring growth and using colorimetric assays as described by Ramamoorthy et al. (2006), Sorensen (1982) and Ogg and Patel (2009). In addition, vanadium(V) reduction was inferred when a green media color and/or a green precipitate was observed, and confirmed using the vanadate assay as described by Carpentier et al. (2003). For this, $250 \mu \mathrm{l}$ of $1 \%(\mathrm{wt} / \mathrm{vol}$ ) diphenylcarbazide (DPC) in acetone was added to $250 \mu \mathrm{l}$ of $2 \mathrm{M} \mathrm{H}_{2} \mathrm{SO}_{4}$, which was combined with $500 \mu \mathrm{l}$ of diluted sample and the absorbance was measured at $320 \mathrm{~nm}$ after $15 \mathrm{~min}$.

Antimicrobial agents

Antibiotic sensitivity of strain RH04- $3^{\mathrm{T}}$ was determined by adding antibiotics from filter-sterilized stock solutions to a final concentration of 10 and $100 \mu \mathrm{g} \mathrm{ml}^{-1}$. To test for growth on $\mathrm{NaCl}$ (range between 0 and 10\%), $\mathrm{NaCl}$ was weighed directly into Hungate tubes, with the medium dispensed and sterilized before use.

Fatty acid composition

The whole-cell fatty acid composition of strain RH04- $3^{\mathrm{T}}$ was determined by DSMZ, using cells grown with lactate and sulfate as the electron donor and acceptor, respectively. 
In previous studies, the closest relatives of strain RH04- ${ }^{\mathrm{T}}$, D. hydrothermale DSM $18033^{\mathrm{T}}$ and D. putei DSM $12395^{\mathrm{T}}$, had been grown under the same conditions. Fatty acid methyl esters were prepared from $40 \mathrm{mg}$ of cells using minor modifications of the method of Miller (1982) and Kuykendall et al. (1988), and were separated and analyzed using Sherlock Microbial Identification System (MIDI 1999).

\section{DNA isolation}

High molecular weight (HMW) DNA was isolated using the previously described method (Marmur 1961; Ogg and Patel 2009).

Determination of $\mathrm{G}+\mathrm{C}$ content

High molecular weight (HMW) DNA of strain RH04-3 $3^{\text {T }}$ was amplified as described, by using a TempliPhi Amplification Kit (Amersham Biosciences, UK) and the mol \% $\mathrm{G}+\mathrm{C}$ content was determined by the thermal denaturation method (Marmur and Doty 1962) in a Cintra20 spectrophotometer (GBC Scientific Equipment, Australia) as described by Ogg and Patel (2009).

16S rRNA sequence studies

16S rRNA gene amplification, sequencing and analysis were determined using the method of Ogg and Patel (2009). The GenBank Accession number for strain RH04$3^{\mathrm{T}}=\mathrm{KCTC} 5794^{\mathrm{T}}=\mathrm{JCM} 16158^{\mathrm{T}}(\mathrm{T}=$ type strain $)$ is GU126374.

\section{Results}

\section{Enrichment and isolation}

Of the 24 wells that contained the electron donors peptone, tryptone, glycerol, formate, pyruvate, 2-methoxybenzoate, 4-methoxybenzoate and adipate (Table 1), 8 produced black precipitates of $\mathrm{FeS}$ following the addition of $\mathrm{Fe}\left(\mathrm{NH}_{4}\right)_{2}\left(\mathrm{SO}_{4}\right)_{2}$, which could suggest that sulfate reduction had occurred. Subsequently, all enrichments with the exception of 2-methoxybenzoate and 4-methoxybenzoate were successfully subcultured and showed growth as well as sulfate reduction. We report in this paper, our studies on strains isolated from the tryptone and glycerol enrichments. 16S rRNA gene sequence analysis of 1,000 nucleotides of strain RG04, an isolate from the tryptone enrichment, revealed a $100 \%$ similarity to Caloramator australicus strain $\mathrm{RC} 3^{\mathrm{T}}$. We had previously reported on the isolation and characterization of Caloramator australicus strain

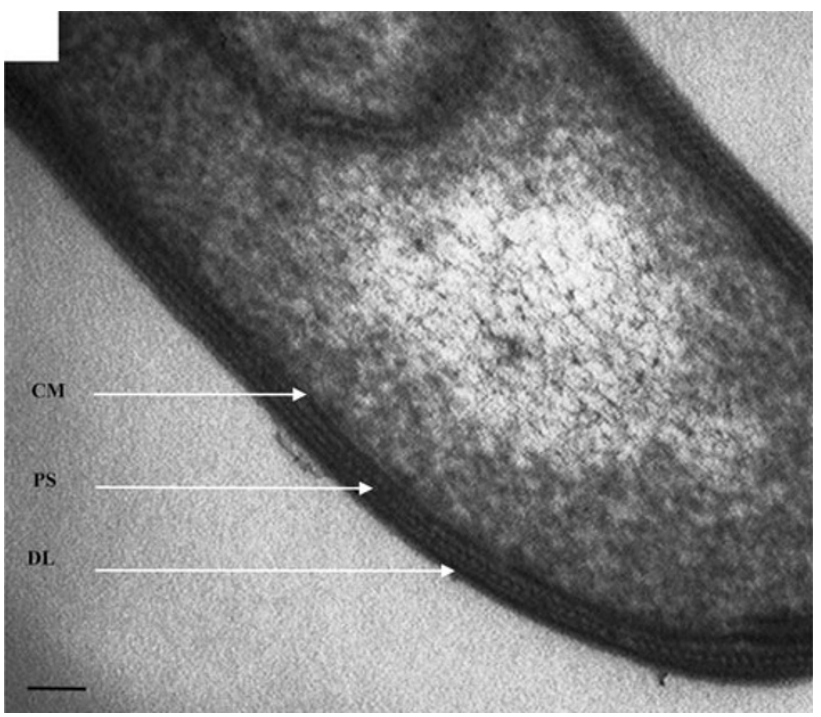

Fig. 1 Transmission electron micrographs of a thin section of cells of strain RH04-3 $3^{\mathrm{T}}$ showing electron-dense protein subunits (PS) situated between an electron-dense cell membrane (CM) and an outer diffused layer (DL), typical of a Gram-positive cell wall ultrastructure. Bar $50 \mathrm{~nm}$

$\mathrm{RC}^{\mathrm{T}}$ from the red mat habitat (Ogg and Patel 2009). Neither strain RG04 nor Caloramator australicus strain $\mathrm{RC} 3^{\mathrm{T}}$ reduce sulfate to sulfide, but rather produce hydrogen sulfide from tryptone metabolism, which reacts with $\mathrm{Fe}\left(\mathrm{NH}_{4}\right)_{2}\left(\mathrm{SO}_{4}\right)_{2}$ to produce the black precipitate. Other thermophilic anaerobes such as Thermoanaerobacter thermohydrosulfuricus (formerly Clostridium thermohydrosulfuricum) also produce hydrogen sulfide from tryptone, peptone and yeast extract metabolism and not from sulfate reduction (Lee et al. 1993). Given the extremely close phylogenetic similarity of strain RG04 to Caloramator australicus strain $\mathrm{RC} 3^{\mathrm{T}}$, further studies were not performed. Five strains, designated RH04-1, RH04-2, RH04-3, RH04-7 and RH04-8, were isolated from the glycerol enrichment culture. 16S rRNA sequence comparisons revealed that all five isolates had a similarity value of $100 \%$. Furthermore, all strains were morphologically identical and had the same substrate utilization pattern and hence only one representative strain, RH04- $3^{\mathrm{T}}$, was designated the type strain and characterized further.

\section{Morphology}

The cells of strain RH04- $3^{\mathrm{T}}$ were straight to slightly curved rods $(2.0-5.0 \times 1.0 \mu \mathrm{m})$, which existed singly, in pairs and short chains, were peritrichously flagellated and regularly formed terminal to sub-terminal oval-shaped spores. Strain RH04-3 ${ }^{\mathrm{T}}$ stained Gram positive and electron micrographs of thin sections revealed cell walls composed of electron-dense protein subunits sandwiched between an 


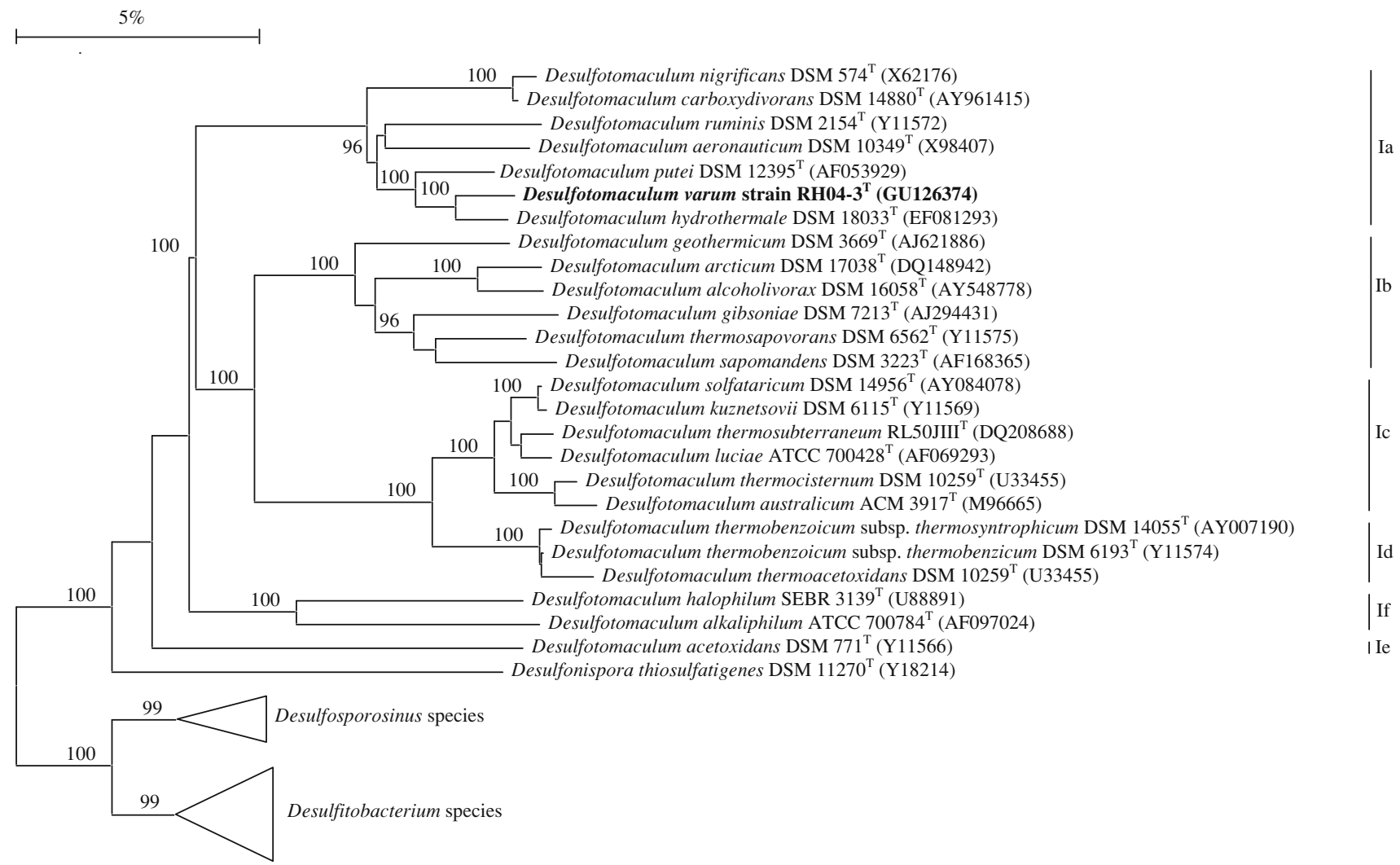

Fig. 2 A dendrogram of the phylogenetic position of Desulfotomaculum varum strain RH04-3 $3^{\mathrm{T}}$ and its closest relatives. Desulfotomaculum clusters Ia to If. Triangles indicate outgroups and include: Desulfosporosinus meridiei DSM $13257^{\mathrm{T}}$ (AF076527), Desulfosporosinus auripigmenti DSM $13351^{\mathrm{T}}$ (AJ493051) and Desulfosporosinus orientis DSM $765^{\mathrm{T}}$ (Y11570) representing members of the genus Desulfosporosinus, and Desulfitobacterium metallireducens

electron-dense inner cell membrane and an outer diffused layer, typical of Gram-positive cell wall ultrastructure (Fig. 1) similar to Desulfotomaculum australicum (Love et al. 1993) and Thermoanaerobacter brockii (formerly Thermoanaerobium brockii) (Zeikus et al. 1979; Patel et al. 1986).

Optimum growth conditions

Strain RH04-3 ${ }^{\mathrm{T}}$ grew optimally at $50{ }^{\circ} \mathrm{C}$ (temperature growth range between 37 and $\left.55^{\circ} \mathrm{C}\right)$ and a $\mathrm{pH}$ of $7(\mathrm{pH}$ growth range of 5.0 and 8.5 ) with $0.2 \%$ glycerol as the electron donor and $20 \mathrm{mM}$ sulfate as the electron acceptor, and in sulfate-free PL medium amended with $0.25 \%$ pyruvate. Growth occurred in the absence of vitamins and trace elements, but required trace amounts of yeast extract for growth on carbon sources. Higher concentrations of yeast extract did not support growth in the absence of any other added carbon sources. Strain RH04- $3^{\mathrm{T}}$ did not grow
DSM $15288^{\mathrm{T}}$ (AF297871), Desulfitobacterium dehalogenans DSM

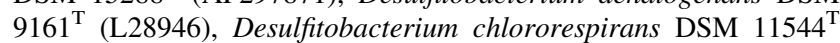
(U68528) and Desulfitobacterium hafniense DSM $10664^{\mathrm{T}}$ (U40078) representing members of the genus Desulfitobacterium. The scale bar indicates five nucleotide changes per 100 nucleotides, bootstrap values $>95$ are shown and GenBank accession numbers are given in parentheses

under aerobic conditions in medium D (Brock and Freeze 1969), or in aerobically prepared PL medium amended with $0.2 \%$ pyruvate.

Substrates and electron acceptor studies

Strain RH04- $3^{\mathrm{T}}$ utilized fructose, mannose, glycerol, lactate and pyruvate, but not glucose, lactose, ethanol, malate, acetate, propionate, formate, succinate, casamino acids, benzoate, butyrate, propanol, methanol and butanol. In the absence of sulfate, pyruvate was fermented, but not fructose, mannose, glycerol, lactate, acetate, malate, formate, ethanol, butanol or propanol. Strain RH04- $3^{\mathrm{T}}$ utilized $\mathrm{H}_{2}$ but not $\mathrm{CO}_{2}$, in the presence or absence of $2 \mathrm{mM}$ acetate and sulfate.

Strain RH04- $3^{\mathrm{T}}$ reduced sulfate, sulfite, thiosulfate and elemental sulfur, but not fumarate, nitrate, nitrite, iron(III), arsenate(V), vanadium(V) or cobalt(III).

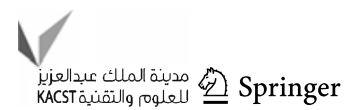


Table 2 Cellular fatty acid composition (\%) of strain RH04-3 $3^{\mathrm{T}}, D$. hydrothermale DSM $18033^{\mathrm{T}}$ and D. putei DSM $12395^{\mathrm{T}}$

\begin{tabular}{|c|c|c|c|}
\hline Fatty acid & 1 & $2^{\mathrm{a}}$ & $3^{\mathrm{a}}$ \\
\hline \multicolumn{4}{|c|}{ Saturated straight chain } \\
\hline $12: 0$ & 0.3 & - & - \\
\hline $14: 0$ & 3.9 & 3.0 & 0.9 \\
\hline $15: 0$ & 0.4 & - & - \\
\hline $16: 0$ & 19.8 & 17.7 & 10.7 \\
\hline 17:0 & 0.5 & - & 1.0 \\
\hline 18:0 & 2.4 & 1.2 & 1.9 \\
\hline \multicolumn{4}{|c|}{ Unsaturated straight chain } \\
\hline 14:0 DMA & 0.2 & - & - \\
\hline 15:0 DMA & - & 0.6 & - \\
\hline $16: 1 c 7$ & 3.6 & 2.4 & 1.3 \\
\hline $16: 1 c 9$ & 8.5 & 8.7 & 3.6 \\
\hline $16: 1 c 11$ & 1.0 & 0.6 & - \\
\hline 16:1 $c 9$ DMA & 1.3 & 2.0 & 0.9 \\
\hline 16:0 DMA & 3.9 & 7.1 & 3.5 \\
\hline 17:0 DMA & 0.1 & - & - \\
\hline 17:0 cyclo & 2.1 & 5.9 & 5.8 \\
\hline $18: 1 c 9$ & 1.0 & 0.7 & 0.8 \\
\hline $18: 1 c 11$ & - & 1.7 & 2.1 \\
\hline $18: 1 c 13$ & 0.5 & - & - \\
\hline 18:1 $c 9 \mathrm{DMA}$ & 0.3 & - & - \\
\hline 18:1 $c 11 \mathrm{DMA}$ & 0.4 & - & - \\
\hline \multicolumn{4}{|l|}{ Aldehyde } \\
\hline 16:0 ALD & 0.7 & 1.1 & - \\
\hline \multicolumn{4}{|c|}{ Saturated branched chain } \\
\hline iso-11:0 & 0.1 & - & - \\
\hline iso-13:0 & 0.3 & - & - \\
\hline iso-14:0 & 0.1 & - & - \\
\hline iso-15:0 & 19.0 & 20.5 & 15.7 \\
\hline iso-15:0 DMA & 0.3 & - & - \\
\hline anteiso-15:0 & 3.3 & 1.2 & 2.0 \\
\hline iso-15:0 $3 \mathrm{OH}$ & 0.3 & - & - \\
\hline iso-16:0 & 0.6 & - & 0.9 \\
\hline iso-17:0 & 15.2 & 16.9 & 35.5 \\
\hline iso-17:0 DMA & 2.7 & 8.2 & 8.5 \\
\hline anteiso-17:0 & 2.9 & 0.5 & 4.3 \\
\hline anteiso-17:0 DMA & 0.5 & - & 0.6 \\
\hline \multicolumn{4}{|l|}{ Summed features } \\
\hline 4 & 0.2 & - & - \\
\hline 6 & 0.2 & - & - \\
\hline 8 & 0.3 & - & - \\
\hline 10 & 3.2 & - & - \\
\hline Total (\%) & 100 & 100 & 100 \\
\hline
\end{tabular}

All strains were grown under the same conditions

Strains: 1 strain RH04-3 ${ }^{\mathrm{T}}, 2$ Desulfotomaculum putei DSM $12395^{\mathrm{T}}, 3$ Desulfotomaculum hydrothermale DSM $18033^{\mathrm{T}}$, ALD aldehyde, DMA dimethyl acetal, - negative

a Data obtained from Haouari et al. (2008)
Antimicrobial agents

Strain RH04-3 ${ }^{\mathrm{T}}$ was completely inhibited in the presence of $10 \mu \mathrm{g} \mathrm{ml}^{-1}$ chloramphenicol, streptomycin, tetracycline, penicillin and ampicillin. Strain RH04- $3^{\mathrm{T}}$ grew in the absence of $\mathrm{NaCl}$, but not with $\mathrm{NaCl}$ concentrations greater than $1.5 \%$ $(\mathrm{w} / \mathrm{v})[\mathrm{NaCl}$ growth range was between 0 and $10 \%(\mathrm{w} / \mathrm{v})]$. Increased growth was observed with $0.1 \% \mathrm{NaCl}(\mathrm{w} / \mathrm{v})$. Under optimum $\mathrm{pH}$ and temperature, strain $\mathrm{RH} 04-3^{\mathrm{T}}$ required at least $0.01 \%(\mathrm{w} / \mathrm{v})$ yeast extract for growth.

$\mathrm{G}+\mathrm{C}$ content

The mol\% $\mathrm{G}+\mathrm{C}$ content of the genomic DNA was calculated to be $52.4 \pm 0.8$.

16S rRNA gene studies

The phylogenetic analysis of the consensus 16S rRNA gene sequence comprising 1,479 nucleotides indicated that strain RH04- $3^{\mathrm{T}}$ was a member of the family Peptococcaceae, class Clostridia, phylum Firmicutes and was most closely related to Desulfotomaculum putei DSM $12395^{\mathrm{T}}$ (similarity value of $95.2 \%$ ) and Desulfotomaculum hydrothermale DSM $18033^{\mathrm{T}}$ (similarity value of $93.6 \%$ ) of genus Desulfotomaculum cluster Ia (Fig. 2). The defining signature nucleotides G:A at position 662/743, A:U at positions $1118 / 1115$ and 1120/1153 (E. coli numbering according to Winkler and Woese 1991) and several other discriminatory nucleotides, distributed in a subcluster Ia at the exclusion of other members of the Desulfotomaculum subclusters, were also identified in the 16S rRNA gene sequence of strain RH04- $3^{\mathrm{T}}$ confirming its phylogenetic placement as a member of subcluster Ia (Table 3).

Fatty acid composition

The whole-cell fatty acid profile of strain $\mathrm{RH} 04-3^{\mathrm{T}}$ revealed a proportionally high level of iso- $\mathrm{C}_{15: 0}, \mathrm{C}_{16: 0}$ and iso- $\mathrm{C}_{17: 0}$, which is consistent with members of the Desulfotomaculum species (Ueki and Suto 1979; Hagenauer et al. 1997; Liu et al. 1997; Love et al. 1993), but quantitative differences in the fatty acid content were also observed in strain RH04- $3^{\mathrm{T}}$ compared to its nearest phylogenetic neighbors, Desulfotomaculum hydrothermale DSM $18033^{\mathrm{T}}$ and Desulfotomaculum putei DSM $12395^{\mathrm{T}}$ (Table 2). These differences include the presence of $\mathrm{C}_{16: 0}$

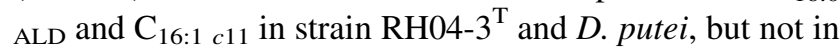
D. hydrothermale (Haouari et al. 2008), and the presence of iso- $\mathrm{C}_{16: 0}, \mathrm{C}_{17: 0}$, and anteiso- $\mathrm{C}_{17: 0}$ DMA in strain RH04- $3^{\mathrm{T}}$ and $D$. hydrothermale, but not in D. putei (data also supported by Haouari et al. 2008). In addition, $\mathrm{C}_{12: 0}, \mathrm{C}_{15: 0}$, $\mathrm{C}_{14: 0 \text { DMA }}, \mathrm{C}_{17: 0 \text { DMA }}, \mathrm{C}_{18: 1 c 13}, \mathrm{C}_{18: 1 c 9 \text { DMA }}, \mathrm{C}_{18: 1 c 11 \text { DMA }}$, 
Table 3 16S rDNA signature nucleotides in Desulfotomaculum subclusters Ia through to If

\begin{tabular}{|c|c|c|c|c|c|c|c|}
\hline \multirow{2}{*}{ E. coli positions } & \multirow[t]{2}{*}{ E. coli } & \multicolumn{6}{|c|}{ Signature nucleotide(s) in: } \\
\hline & & $\begin{array}{l}\text { Subcluster Ia } \\
\text { (7 strains) }\end{array}$ & $\begin{array}{l}\text { Subcluster Ib } \\
\text { (6 strains) }\end{array}$ & $\begin{array}{l}\text { Subcluster Ic } \\
\text { (6 strains) }\end{array}$ & $\begin{array}{l}\text { Subcluster Id } \\
\text { (3 strains) }\end{array}$ & $\begin{array}{l}\text { Subcluster Ie } \\
\text { (1 strain) }\end{array}$ & $\begin{array}{l}\text { Subcluster If } \\
\text { (2 strains) }\end{array}$ \\
\hline $66-103$ & $\mathrm{~A}-\mathrm{U}$ & $\mathrm{A}-\mathrm{U}$ & $\mathrm{A}-\mathrm{U}$ & $\mathrm{G}-\mathrm{C}$ & $\mathrm{G}-\mathrm{C}$ & $\mathrm{A}-\mathrm{U}$ & $\mathrm{A}-\mathrm{U}$ \\
\hline \multirow[t]{2}{*}{ 154-167 } & $\mathrm{U}-\mathrm{A}$ & $\mathrm{A}-\mathrm{U}$ & $\mathrm{G}-\mathrm{U}$ & $\mathrm{G}-\mathrm{C}$ & Pur-Pyr & $\mathrm{G}-\mathrm{U}$ & $\mathrm{A}-\mathrm{U}$ \\
\hline & & & & $\mathrm{G}-\mathrm{G}$ & & & U-A \\
\hline 157-164 & U-G & U-G & G-Pyr & $\mathrm{G}-\mathrm{U}$ & G-Pyr & $\mathrm{G}-\mathrm{C}$ & $\mathrm{G}-\mathrm{C}$ \\
\hline 184 & A & $\mathrm{C}$ & $\mathrm{C}$ & $\mathrm{C}$ & $\mathrm{C}$ & A & $\mathrm{C}$ \\
\hline $252-274$ & $\mathrm{U}-\mathrm{A}$ & $\mathrm{U}-\mathrm{A}$ & $\mathrm{U}-\mathrm{A}$ & $\mathrm{A}-\mathrm{U}$ & $\mathrm{A}-\mathrm{U}$ & $\mathrm{U}-\mathrm{A}$ & $\mathrm{U}-\mathrm{A}$ \\
\hline \multirow[t]{2}{*}{$259-267$} & $\mathrm{G}-\mathrm{C}$ & $\mathrm{U}-\mathrm{A}$ & $\mathrm{G}-\mathrm{C}$ & $\mathrm{G}-\mathrm{C}$ & $\mathrm{G}-\mathrm{C}$ & $\mathrm{G}-\mathrm{C}$ & $\mathrm{G}-\mathrm{C}$ \\
\hline & & & & & & & $\mathrm{U}-\mathrm{A}$ \\
\hline 293-304 & $\mathrm{G}-\mathrm{U}$ & $\mathrm{G}-\mathrm{C}$ & $\mathrm{G}-\mathrm{C}$ & Pur-U & $\mathrm{G}-\mathrm{U}$ & $\mathrm{G}-\mathrm{U}$ & G-Pyr \\
\hline $320-333$ & $\mathrm{~A}-\mathrm{U}$ & $\mathrm{G}-\mathrm{C}$ & $\mathrm{A}-\mathrm{U}$ & $\mathrm{G}-\mathrm{C}$ & $\mathrm{G}-\mathrm{C}$ & $\mathrm{A}-\mathrm{U}$ & Pur-Pyr \\
\hline 381 & $\mathrm{C}$ & A & $\mathrm{C}$ & A & A & A & A \\
\hline $409-433$ & U-G & $\mathrm{G}-\mathrm{C}$ & Pyr-Pur & $\mathrm{C}-\mathrm{G}$ & $\mathrm{C}-\mathrm{G}$ & $\mathrm{C}-\mathrm{G}$ & $\mathrm{G}-\mathrm{C}$ \\
\hline \multirow[t]{2}{*}{427} & $\mathrm{U}$ & $\mathrm{U}$ & $\mathrm{U}$ & $\mathrm{C}$ & $\mathrm{C}$ & $\mathrm{U}$ & $\mathrm{U}$ \\
\hline & & & & & & & A \\
\hline $440-494$ & $\mathrm{C}-\mathrm{G}$ & Pyr-G & $\mathrm{C}-\mathrm{G}$ & $\mathrm{U}-\mathrm{G}$ & $\mathrm{U}-\mathrm{G}$ & $\mathrm{G}-\mathrm{G}$ & $\mathrm{U}-\mathrm{G}[\mathrm{y}-\mathrm{G}]$ \\
\hline \multirow[t]{3}{*}{$444-490$} & $\mathrm{G}-\mathrm{C}$ & $\mathrm{A}-\mathrm{U}$ & $\mathrm{G}-\mathrm{C}$ & $\mathrm{G}-\mathrm{C}$ & $\mathrm{G}-\mathrm{C}$ & $\mathrm{U}-\mathrm{A}$ & $\mathrm{U}-\mathrm{A}$ \\
\hline & & & $\mathrm{A}-\mathrm{U}$ & & & & \\
\hline & & & $\mathrm{A}-\mathrm{A}$ & & & & \\
\hline 449 & G & A & A & A & $\mathrm{C}$ & $\mathrm{C}$ & A \\
\hline 534 & $\mathrm{U}$ & A & A & G & G & $\mathrm{U}$ & $\mathrm{C}$ \\
\hline 580 & $\mathrm{C}$ & $\mathrm{C}$ & $\mathrm{U}$ & $\mathrm{C}$ & $\mathrm{C}$ & A & $\mathrm{C}$ \\
\hline 582 & $\mathrm{C}$ & $\mathrm{U}$ & $\mathrm{U}$ & $\mathrm{U}$ & $\mathrm{C}$ & $\mathrm{U}$ & $\mathrm{U}$ \\
\hline 586-755 & $\mathrm{C}-\mathrm{G}$ & $\mathrm{U}-\mathrm{A}$ & $\mathrm{C}-\mathrm{G}$ & $\mathrm{C}-\mathrm{G}$ & $\mathrm{C}-\mathrm{G}$ & $\mathrm{U}-\mathrm{A}$ & $\mathrm{C}-\mathrm{G}$ \\
\hline $589-650$ & $\mathrm{U}-\mathrm{G}$ & $\mathrm{U}-\mathrm{A}$ & $\mathrm{C}-\mathrm{G}$ & Pyr-Pur & $\mathrm{C}-\mathrm{G}$ & $\mathrm{U}-\mathrm{A}$ & Pyr-Pur \\
\hline 593-646 & $\mathrm{U}-\mathrm{G}$ & $\mathrm{U}-\mathrm{G}$ & G-Pyr & $\mathrm{A}-\mathrm{U}$ & $\mathrm{A}-\mathrm{U}$ & $\mathrm{U}-\mathrm{G}$ & $\mathrm{U}-\mathrm{G}$ \\
\hline \multirow[t]{2}{*}{ 603-635 } & $\mathrm{U}-\mathrm{A}$ & $\mathrm{G}-\mathrm{C}$ & $\mathrm{A}-\mathrm{U}$ & $\mathrm{G}-\mathrm{C}$ & $\mathrm{G}-\mathrm{C}$ & $A-T$ & $\mathrm{G}-\mathrm{C}$ \\
\hline & & & $\mathrm{T}-\mathrm{G}$ & & & & \\
\hline 610-630 & $\mathrm{U}-\mathrm{A}$ & G-A & $\mathrm{C}-\mathrm{C}$ & $\mathrm{U}-\mathrm{G}$ & $\mathrm{U}-\mathrm{G}$ & $\mathrm{A}-\mathrm{A}$ & G-Pur \\
\hline 657-749 & $\mathrm{U}-\mathrm{A}$ & $\mathrm{U}-\mathrm{A}$ & $\mathrm{U}-\mathrm{A}$ & $\mathrm{G}-\mathrm{C}$ & $\mathrm{G}-\mathrm{C}$ & U-A & $\mathrm{U}-\mathrm{A}$ \\
\hline \multirow[t]{3}{*}{$662-743^{\mathrm{a}}$} & $\mathrm{U}-\mathrm{A}$ & G-A & $\mathrm{G}-\mathrm{C}$ & G-Pyr & $\mathrm{G}-\mathrm{C}$ & $\mathrm{G}-\mathrm{C}$ & $\mathrm{G}-\mathrm{C}$ \\
\hline & & & $\mathrm{A}-\mathrm{C}$ & & & & \\
\hline & & & $\mathrm{T}-\mathrm{C}$ & & & & \\
\hline 672 & $\mathrm{U}$ & $\mathrm{C}$ & $\mathrm{U}$ & $\mathrm{U}$ & $\mathrm{U}$ & $\mathrm{U}$ & $\mathrm{U}$ \\
\hline 681-709 & $\mathrm{A}-\mathrm{U}$ & $\mathrm{C}-\mathrm{G}$ & $\mathrm{C}-\mathrm{G}$ & $\mathrm{C}-\mathrm{G}$ & $\mathrm{C}-\mathrm{G}$ & $\mathrm{U}-\mathrm{A}$ & Pyr-A \\
\hline 682-708 & $\mathrm{A}-\mathrm{U}$ & $\mathrm{A}-\mathrm{U}$ & $\mathrm{A}-\mathrm{U}$ & $\mathrm{G}-\mathrm{C}$ & $\mathrm{G}-\mathrm{C}$ & $\mathrm{A}-\mathrm{U}$ & $\mathrm{A}-\mathrm{U}$ \\
\hline 730 & G & G & A & G & G & G & G \\
\hline 738 & $\mathrm{C}$ & $\mathrm{U}$ & $\mathrm{C}$ & $\mathrm{U}$ & $\mathrm{U}$ & $\mathrm{C}$ & $\mathrm{C}$ \\
\hline 776 & G & G & $\mathrm{U}$ & G & G & $\mathrm{G}$ & $\mathrm{U}$ \\
\hline 778 & G & G & G & G & G & $\mathrm{U}$ & G \\
\hline $822-878$ & $\mathrm{U}-\mathrm{A}$ & $\mathrm{A}-\mathrm{U}$ & G-Pyr & $\mathrm{G}-\mathrm{C}$ & $\mathrm{G}-\mathrm{C}$ & $\mathrm{A}-\mathrm{U}$ & $\mathrm{A}-\mathrm{U}$ \\
\hline 896-903 & $\mathrm{C}-\mathrm{G}$ & $\mathrm{U}-\mathrm{A}^{\mathrm{b}}$ & $\mathrm{C}-\mathrm{G}$ & $\mathrm{C}-\mathrm{G}$ & $\mathrm{C}-\mathrm{G}$ & $\mathrm{U}-\mathrm{A}$ & $\mathrm{U}-\mathrm{A}$ \\
\hline \multirow[t]{2}{*}{$948-1233$} & $\mathrm{C}-\mathrm{G}$ & $\mathrm{U}-\mathrm{A}$ & G-A & $\mathrm{C}-\mathrm{G}$ & $\mathrm{C}-\mathrm{G}$ & $\mathrm{U}-\mathrm{A}$ & $\mathrm{C}-\mathrm{G}$ \\
\hline & & & $\mathrm{C}-\mathrm{G}$ & & & & \\
\hline 989-1216 & $\mathrm{U}-\mathrm{A}$ & $\mathrm{G}-\mathrm{U}$ & $\mathrm{U}-\mathrm{A}$ & $\mathrm{G}-\mathrm{U}$ & $\mathrm{G}-\mathrm{U}$ & $\mathrm{G}-\mathrm{U}$ & Pur-U \\
\hline 1217 & $\mathrm{C}$ & $\mathrm{C}$ & $\mathrm{U}$ & $\mathrm{C}$ & $\mathrm{C}$ & $\mathrm{C}$ & $\mathrm{C}$ \\
\hline $1118-1155^{\mathrm{a}}$ & $\mathrm{U}-\mathrm{A}$ & $\mathrm{A}-\mathrm{U}$ & $\mathrm{C}-\mathrm{G}$ & $\mathrm{C}-\mathrm{G}$ & $\mathrm{C}-\mathrm{G}$ & $\mathrm{C}-\mathrm{G}$ & $\mathrm{C}-\mathrm{G}$ \\
\hline
\end{tabular}


Table 3 continued

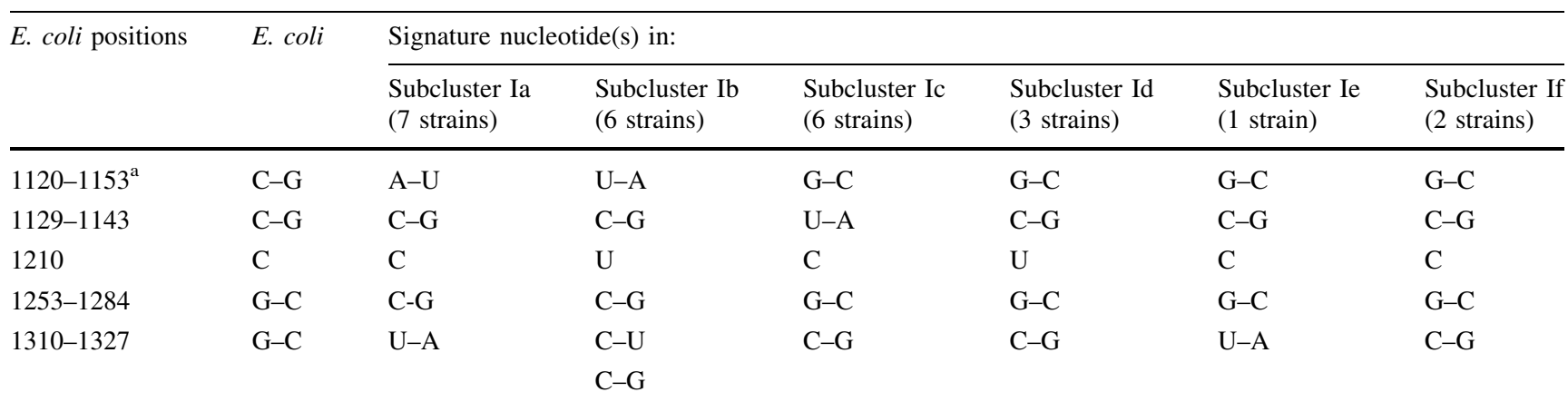

Subcluster Ia is composed of: D. nigrificans DSM $574^{\mathrm{T}}$ (X62176), D. carboxydivorans DSM $14880^{\mathrm{T}}$ (AY961415), D. ruminis DSM 2154 ${ }^{\mathrm{T}}$ (Y11572), D. aeronauticum DSM 10349 ${ }^{\mathrm{T}}$ (X98407), D. putei DSM 12395 ${ }^{\mathrm{T}}$ (AF053929), D. varum strain RH04-3 ${ }^{\mathrm{T}}$ (GU126374) and D. hydrothermale DSM $18033^{\mathrm{T}}$ (EF081293). Subcluster Ib is composed of: D. geothermicum DSM $3669^{\mathrm{T}}$ (AJ621886), D. arcticum DSM 17038 ${ }^{\mathrm{T}}$ (DQ148942), D. alcoholivorax DSM 16058 ${ }^{\mathrm{T}}$ (AY548778), D. gibsoniae DSM 7213 ${ }^{\mathrm{T}}$ (AJ294431), D. thermosapovorans DSM 6562 ${ }^{\mathrm{T}}$ (Y11575) and D. sapomandens DSM $3223^{\mathrm{T}}$ (AF168365). Subcluster Ic is composed of: D.solfataricum DSM $14956^{\mathrm{T}}$ (AY084078), D. kuznetsovii DSM $6115^{\mathrm{T}}$ (Y11569), D.thermosubterraneum RL50JIII ${ }^{\mathrm{T}}$ (DQ208688), D. luciae ATCC 700428 ${ }^{\mathrm{T}}$ (AF069293), D. thermocisternum DSM $10259^{\mathrm{T}}$ and D. australicum ACM $3917^{\mathrm{T}}$ (M96665). Subcluster Id is composed of: D. thermobenzoicum subsp. thermosyntrophicum DSM 14055 ${ }^{\mathrm{T}}$ (AY007190), D. thermobenzoicum subsp. thermobenzicum DSM $6193^{\mathrm{T}}$ (Y11574) and D. thermoacetoxidans DSM 10259 ${ }^{\mathrm{T}}$ (U33455). Subcluster Ie is composed of D. acetoxidans DSM $771^{\mathrm{T}}$ (Y11566). Subcluster If is composed of D. halophilum SEBR 3139 ${ }^{\mathrm{T}}$ (U88891) and D. alkaliphilum ATCC $700784^{\mathrm{T}}$ (AF097024)

Pur purine, Pyr Pyrimidine

${ }^{a}$ Subcluster Ia-specific nucleotide positions

${ }^{\mathrm{b}}$ E. coli position 903 for D. nigrificans DSM $574^{\mathrm{T}}$ (X62176) is not defined (N)

iso- $\mathrm{C}_{11: 0}$, iso- $\mathrm{C}_{13: 0}$, iso- $\mathrm{C}_{14: 0}$, iso- $\mathrm{C}_{15: 0}$ DMA and iso- $\mathrm{C}_{15: 0}$ $3 \mathrm{OH}$ were present in small quantities in strain RH04- $3^{\mathrm{T}}$, but not in D. putei and D. hydrothermale.

\section{Discussion}

Strain RH04- $3^{\mathrm{T}}$ exhibits phenotypic traits that are consistent with members of the genus Desulfotomaculum, which includes the Gram-positive nature of the cell wall ultrastructure, strictly anaerobic growth, the ability to form spores, sulfate reduction, a DNA $\mathrm{G}+\mathrm{C}$ mol\% content between 50 and $60 \%$ and the dominant presence of iso$\mathrm{C}_{15: 0}, \mathrm{C}_{16: 0}, \mathrm{C}_{18: 0}$ and iso- $\mathrm{C}_{17: 0}$ in the whole-cell fatty acids. Strain RH04- $3^{\mathrm{T}}$ shares exclusively with its phylogenetic relatives in Desulfotomaculum cluster Ia the ability to form oval-shaped spores, growth in the absence of $\mathrm{NaCl}$, fermentation of pyruvate, reduction of thiosulfate and utilization of $\mathrm{H}_{2}$ and lactate, but not malate, and the defining signature nucleotides G:A at position 662/743, A:U at position $1118 / 1115$ and $\mathrm{A}: \mathrm{U}$ at position $1120 / 1153$ (E. coli numbering according to Winkler and Woese 1991) are consistent with the placement of strain $\mathrm{RH} 04-3^{\mathrm{T}}$ as a member of cluster Ia (Table 3). Strain RH04- $3^{\mathrm{T}}$ shares a few phenotypic characteristics with its nearest phylogenetic relatives, D. hydrothermale DSM $18033^{\mathrm{T}}$ (Haouari et al. 2008) and D. putei DSM $12395^{\mathrm{T}}$ (Liu et al. 1997), which include similar cell length and width, optimal growth at near neutral $\mathrm{pH}$ values, the ability to reduce sulfite but not nitrate and nitrite, and the inability to utilize glucose, lactose, acetate, propionate, benzoate, butyrate and succinate. However, the presence of a smaller helix 6 (positions 61-106, E. coli numbering according to Winkler and Woese 1991), comprising 32-34 nucleotides in strain RH04-3 ${ }^{\mathrm{T}}$ and Desulfotomaculum putei and a larger helix 6, comprising 80-100 nucleotides in D. hydrothermale (and the nine members of Desulfotomaculum clusters Ic and Id, and $D$. geothermicum, cluster $\mathrm{Ib}$ ), clearly differentiate strain RH04- $3^{\mathrm{T}}$ from $D$. hydrothermale.

Strain RH04- $3^{\mathrm{T}}$ also has many traits that clearly differentiates it from $D$. hydrothermale DSM $18033^{\mathrm{T}}$ and $D$. putei DSM $12395^{\mathrm{T}}$, the two nearest phylogenetic neighbors. The similarity of strain RH04- $3^{\mathrm{T}}$ to $D$. hydrothermale DSM $18033^{\mathrm{T}}$ and $D$. putei DSM $12395^{\mathrm{T}}$ is only 93.6 and 95.2\% respectively, the temperature optima for growth, the temperature growth range, $\mathrm{pH}$ growth range, yeast extract requirement for growth, mol $\% \mathrm{G}+\mathrm{C}$ content of the DNA, range of electron acceptors used, the range of substrates used (Table 4), and the whole-cell fatty acid composition (Table 2) also differentiate the three isolates. Based on the phenotypic and phylogenetic differences, we suggest that strain RH04- $3^{\mathrm{T}}$ represents a novel species for which the name Desulfotomaculum varum sp. nov., is proposed.

Description of Desulfotomaculum varum sp. nov

Desulfotomaculm varum (va'. rum M. L. adj varum bent, bow legged pertaining to the slightly curved cell shape). 
Table 4 Differential characteristics of strain RH04-3 $3^{\mathrm{T}}$ and its closest relatives

\begin{tabular}{|c|c|c|c|}
\hline Characteristic & 1 & 2 & 3 \\
\hline Geographical location & $\begin{array}{l}\text { Microbial mats from a thermal aquifer bore } \\
\text { well outflow }\end{array}$ & $\begin{array}{l}\text { Siltstone from a deep terrestrial } \\
\text { subsurface }\end{array}$ & Hot spring \\
\hline Habitat & Great Artesian Basin, Australia & Tayolrsville Triassic Basin, USA & $\begin{array}{l}\text { Hamam Essalhine hot spring, } \\
\text { Tunisia }\end{array}$ \\
\hline Morphology & Straight to slightly curved rod-shaped & ND & Slightly curved rod shaped \\
\hline Length $(\mu \mathrm{m})$ & $2.0-5.0$ & $2.0-5.0$ & $3.0-6.0$ \\
\hline Width $(\mu \mathrm{m})$ & 1.0 & $1.0-1.1$ & 1.0 \\
\hline Gram-stain & Positive & Negative & Negative \\
\hline Cell-wall ultrastructure & Negative & Positive & Positive \\
\hline \multicolumn{4}{|l|}{$\begin{array}{l}\text { Temperature growth range } \\
\left({ }^{\circ} \mathrm{C}\right)\end{array}$} \\
\hline Optimum & 50 & 64 & 55 \\
\hline Range & $37-55$ & $40-65$ & $40-60$ \\
\hline \multicolumn{4}{|l|}{$\mathrm{pH}$ growth range } \\
\hline Optimum & 7 & 7.5 & 7 \\
\hline Range & $5-8.5$ & $6-7.9$ & $5.8-8.2$ \\
\hline $\mathrm{NaCl}$ growth range $[\%(\mathrm{w} / \mathrm{v})]$ & $0-1$ & $0-2$ & $0-1.5$ \\
\hline Yeast extract requirement & + & ND & - \\
\hline \multicolumn{4}{|c|}{ Utilization of electron donors with sulfate } \\
\hline Fructose & + & + & - \\
\hline Mannose & + & ND & - \\
\hline Ethanol & - & + & + \\
\hline Butanol & - & ND & + \\
\hline Methanol & - & + & - \\
\hline Propanol & - & ND & + \\
\hline Formate & - & + & + \\
\hline Pyruvate & + & + & + \\
\hline \multicolumn{4}{|l|}{ Substrates fermented } \\
\hline Fructose & - & + & - \\
\hline \multicolumn{4}{|l|}{ Electron acceptors } \\
\hline Iron(III) & - & - & + \\
\hline $\operatorname{As}(\mathrm{V})$ & - & ND & + \\
\hline DNA G $+\mathrm{C}$ content $(\mathrm{mol} \%)$ & $52.4^{\mathrm{a}}$ & $47.1^{\mathrm{b}}$ & $46.9^{\mathrm{b}}$ \\
\hline $\begin{array}{l}\text { 16S rRNA similarity to } \\
\text { RH04-3 } 3^{\mathrm{T}}(\%)\end{array}$ & 100 & 95.2 & 93.6 \\
\hline
\end{tabular}

Strains: 1 strain RH04-3 $3^{\mathrm{T}}, 2$ Desulfotomaculum putei (Liu et al. 1997), 3 Desulfotomaculum hydrothermale (Haouari et al. 2008), + positive, - negative, $N D$ not determined

${ }^{a}$ Determined by the thermal denaturation method

b Determined by HPLC

Cells are strictly anaerobic, thermophilic, straight to slightly curved rods $(2.0-5.0 \times 1.0 \mu \mathrm{m})$ that stain Grampositive and possess a Gram-positive cell wall ultrastructure. Cells possess peritrichous flagella and produce oval, subterminal to terminal spores. Growth occurs between 37 and $55^{\circ} \mathrm{C}$ (optimum temperature $50{ }^{\circ} \mathrm{C}$ ) and $\mathrm{pH} 5.0-8.5$ (optimum pH 7). Sulfate, sulfite, thiosulfate and elemental sulfur are used as electron acceptors but not fumarate, nitrate, nitrite, iron(III), arsenate $(\mathrm{V})$, vanadium $(\mathrm{V})$ or
cobalt(III). Electron donors used in the presence of sulfate as an electron acceptor include glycerol, fructose, mannose, lactate, pyruvate and $\mathrm{H}_{2}$, but not glucose, lactose, ethanol, malate, acetate, propionate, formate, benzoate, succinate, butyrate, casamino acids, propanol, methanol and butanol. In the absence of sulfate, pyruvate was fermented, but not fructose, mannose, glycerol, lactate, acetate, malate, formate, ethanol, butanol and propanol. Sensitive to chloramphenicol, streptomycin, tetracycline, penicillin, 
ampicillin and $\mathrm{NaCl}$ concentrations greater than $1.5 \%$. The $\mathrm{G}+\mathrm{C}$ content of the genomic DNA is $52.4 \pm 0.8 \mathrm{~mol}$ $\%$. Phylogenetically related to members of the genus Desulfotomaculum, most closely to Desulfotomaculum hydrothermale (16S rRNA similarity of 93.6\%) and Desulfotomaculum putei (16S rRNA similarity of 95.2\%). The type strain $\mathrm{RH} 04-3^{\mathrm{T}} \quad\left(=\mathrm{KCTC}=5794^{\mathrm{T}}=\mathrm{JCM}\right.$ $16158^{\mathrm{T}}$ ) was isolated from a microbial mat sample from the outflow of a Great Artesian Basin bore well (the New Lorne Bore) in Queensland, Australia.

Acknowledgments We thank Dr Deborah Stenzel, QUT, for assistance in electron microscopy. Christopher D. Ogg is a recipient of Griffith University's Australian Post-Graduate Research Award (APRA)

Open Access This article is distributed under the terms of the Creative Commons Attribution License which permits any use, distribution and reproduction in any medium, provided the original author(s) and source are credited.

\section{References}

Beeder J, Torsvik T, Lien T (1995) Thermodesulforhabdus norvegicus gen. nov., sp. nov., a novel thermophilic sulfate-reducing bacterium from oil field water. Arch Microbiol 164:331-336

Brock TD, Freeze H (1969) Thermus aquaticus gen. nov., a nonsporulating extreme thermophile. J Bacteriol 98:289-297

Campbell LL, Postgate JR (1965) Classification of spore-forming sulfate-reducing bacteria. Bacteriol Rev 29:359-363

Carpentier W, Sandra K, De Smet I, Brige A, De Smet L, Van Beeumen J (2003) Microbial reduction and precipitation of vanadium by Shewanella oneidensis. Int J Syst Evol Microbiol 69:3636-3639

Habermehl MA (1980) The Great Artesian Basin, Australia. BMR J Aust Geol Geophys 5:9-38

Hagenauer A, Hippe H, Rainey FA (1997) Desulfotomaculum aeronauticum sp. nov., a spore forming, thiosulfate-reducing bacterium from corroded aluminium alloy in an aircraft. Syst Appl Microbiol 20:65-71

Haouari O, Fardeau M-L, Cayol J-L, Casiot C, Elbaz-Poulichet F, Hamdi M, Joseph M, Ollivier B (2008) Desulfotomaculum hydrothermale sp. nov., a thermophilic sulfate-reducing bacterium isolated from a terrestrial Tunisian hot spring. Int J Syst Evol Microbiol 58:2529-2535

Henry EA, Devereux R, Maki JS, Gilmour CC, Woese CR, Mandelco L, Schauder R, Remsen CC, Mitchell R (1994) Thermodesulfovibrio yellowstonii, gen. nov. and sp. nov.: its phylogenetic relationship to Thermodesulfobacterium commune and their origins deep within the bacterial domain. Arch Microbiol 161:62-69

Kaksonen AH, Spring S, Schumann P, Kroppenstedt RM, Puhakka JA (2007a) Desulfovirgula thermocuniculi gen. nov., a thermophilic sulfate-reducer isolated from a geothermal underground mine in Japan. Int J Syst Evol Microbiol 57:98-102

Kaksonen AH, Spring S, Schumann P, Kroppenstedt RM, Puhakka JA (2007b) Desulfurispora thermophila gen. nov., sp. nov., a thermophilic, spore-forming sulfate-reducer isolated from a sulfidogenic fluidized-bed reactor. Int J Syst Evol Microbiol 57:1089-1094
Kanso S, Patel BKC (2003) Microvirga subterranea gen. nov., sp nov., a moderate thermophile from a deep subsurface Australian thermal aquifer. Int J Syst Evol Microbiol 53:401-406

Kuever J, Rainey FA, Widdel F (2005) Genus III. Desulfothermus gen. nov. in Bergey's manual of systematic bacteriology, 2nd edn. vol 2. In: Brenner DJ, Kreig NR, Staley JT, Garrity GM (eds) The Proteobacteria, part C, The alpha-, beta-, delta-, and epsilon-proteobacteria. New York, Springer, pp 955-956

Kuykendall LD, Roy MA, O’Neill JJ, Devine TE (1988) Fatty acids, antibiotic resistance, and deoxyribonucleic acid homology groups of Bradorhizobium japonicum. Int J Syst Bact 38:358-361

Lee Y-E, Jain MK, Lee C, Zeikus JG (1993) Taxonomic distinction of saccharolytic thermophilic anaerobes: description of Thermoanaerobacterium xylanolyticum gen. nov., sp. nov., and Thermoanaerobacterium saccharolyticum gen. nov., sp. nov.; reclassification of Thermoanaerobium brockii, Clostridium thermosulfurogenes, and Clostridium thermohydrosulfuricum E100-69 as Thermoanaerobacter brockii comb. nov., Thermoanaerobacterium thermosulfurigenes comb. nov., and Thermoanaerobacter thermohydrosulfuricus comb. nov., respectively; and transfer of Clostridium thermohydrosulfuricum 39E to Thermoanaerobacter ethanolicus. Int J Syst Bacteriol 43:41-51

Liu Y, Karnauchow TM, Jarrell KF, Balkwill DL, Drake GR, Ringelberg D, Clarno R, Boone DR (1997) Description of two new thermophilic Desulfotomaculum spp., Desulfotomaculum putei sp. nov., from a deep terrestrial subsurface, and Desulfotomaculum luciae sp. nov., from a hot spring. Int J Syst Bact 47:615-621

Love CA, Patel BKC, Nichols PD, Stackebrandt E (1993) Desulfotomaculum australicum, sp. nov., a thermophilic sulfate-reducing bacterium isolated from the Great Artesian Basin of Australia. Syst Appl Microbiol 16:244-251

Marmur J (1961) A procedure for the isolation of deoxyrinonucleic acid from microorganisms. J Mol Biol 3:208-218

Marmur J, Doty P (1962) Determination of the base composition of deoxyribonucleic acid from its thermal denaturation temperature. J Mol Biol 3:585-594

MIDI (1999) Sherlock microbial identification system, operating manual, version 3.0. MIDI, Inc., Newark, DE

Miller LT (1982) A single derivatization method for bacterial fatty acid methyl esters including hydroxy acids. J Clin Microbiol 16:584-586

Mori K, Kim h, Kakegawa T, Hanada S (2003) A novel lineage of sulfate-reducing microorganisms: Thermosdesulfobiaceae fam. nov., Thermodesulfobium narugense, gen. nov., sp. nov., a new thermophilic isolate from a hot spring. Extremophiles 7:283-290

Moussard H, L'Haridon S, Tindall BJ, Banta A, Schumann P, Stackebrandt E, Reysenbach A-L (2004) Thermodesulfatator indicus gen. nov., sp. nov., a novel thermophilic chemolithoautotrophic sulfate-reducing bacterium isolated from the Central Indian Ridge. Int J Syst Evol Microbiol 54:227-233

Nunoura T, Oida T, Miyazaki M, Suzuki Y (2008) Thermosulfidibacter takaii gen. nov., sp. nov., a thermophilic, hydrogenoxidizing, sulfur-reducing chemolithoautotroph isolated from a deep-sea hydrothermal field in the Southern Okinawa Trough. Int J Syst Evol Microbiol 58:659-665

Ogg CD, Patel BKC (2009) Caloramator australicus sp. nov., a thermophilic, anaerobic bacterium from the Great Artesian Basin of Australia. Int J Syst Evol Microbiol 59:95-101

Patel BKC, Morgan HW, Daniel RM (1985) Fervidobacterium nodosum gen. nov. sp. nov., a new chemoorganotrophic, caldoactive, anaerobic bacterium. Arch Microbiol 141:63-69

Patel BKC, Morgan HW, Daniel RM (1986) Studies on some thermophilic glycolytic anaerobic bacteria from New Zealand hot springs. Syst Appl Microbiol 8:128-136 
Ramamoorthy S, Sass H, Langner H, Schumann P, Kroppenstedt RM, Spring S, Overmann J, Rosenzweig RF (2006) Desulfosporosinus lacus sp. nov., a sulfate-reducing bacterium isolated from pristine freshwater lake sediments. Int J Syst Evol Microbiol 56:2729-2736

Sorensen J (1982) Reduction of ferric iron in anaerobic, marine sediment and interaction with reduction of nitrate and sulfate. Appl Environ Microbiol 43:1472-1480

Spanevello MD (2001) The phylogeny of prokaryotes associated with Australia's Great Artesian Basin. In: School of Biomolecular and Physical Science. Griffith University, Brisbane

Ueki A, Suto T (1979) Cellular fatty acid composition of sulfatereducing bacteria. J Gen Appl Microbiol 25:185-196
Winkler S, Woese CR (1991) A definition of the domains Archaea, Bacteria and Eucarya in terms of small subunit ribosomal RNA characteristics. Syst Appl Microbiol 14:305-310

Wolin EA, Wolin MJ, Wolfe RS (1963) Formation of methane by bacterial extracts. J Biol Chem 238:2882-2886

Zeikus JG, Hegge PW, Anderson MA (1979) Thermoanaerobium brockii gen. nov. and sp. nov., a new chemoorganotrophic, caldoactive, anaerobic bacterium. Arch Microbiol 122:41-48

Zeikus JG, Dawson MA, Thompson TE, Ingvorsen K, Hatchikian EC (1983) Microbial ecology of volcanic sulphidogenesis: isolation and characterization of Thermodesulfobacterium commune gen. nov. and sp. nov. J Gen Microbiol 129:1159-1169 